\title{
Bilateral ocular paralysis in an ocular emergency
}

\author{
Amar Pujari, Ritika Mukhija, Swati Phuljhele, Rohit Saxena
}

R P Centre for Ophthalmic Sciences, All India Institute of Medical Sciences, New Delhi, India

\section{Correspondence to Dr Amar Pujari, dramarpujari@gmail.com}

Accepted 22 May 2018

\section{DESCRIPTION}

\section{Case description}

A 70-year-old female patient was brought to the ocular emergency department with the chief complaints of bilateral severe ptosis and total external ophthalmoplegia $(\mathrm{L}>\mathrm{R})$ for the past 1 week (figure 1). There was no history of any significant medical or surgical intervention. On evaluation, there was a $6 \mathrm{~mm}$ ptosis in the right eye and complete ptosis in the left eye along with an axial proptosis of $20 \mathrm{~mm}$ in the right eye and $21 \mathrm{~mm}$ in the left eye as measured using a Hertel exophthalmometer. Both eyes had complete restriction of extraocular movements in all gazes (figure 1) along with mildly dilated pupils with a sluggish reaction to light. Conjunctiva showed severe chemosis in both eyes $(\mathrm{L}>\mathrm{R})$. The anterior segment was slightly shallow on both sides with nuclear sclerosis of grade I to II. Intraocular pressures were 18 and $20 \mathrm{~mm} \mathrm{Hg}$ in the right and left, respectively. Retinal examination showed severe disc oedema in both eyes along with severe retinal vascular tortuosity.

A contrast-enhanced CT of orbit and head revealed a prominent and dilated superior ophthalmic veins on both sides in absence of any other significant orbital findings (figure $2 \mathrm{~A}$, B). However, there was a definite enhancement along the cavernous sinus on either side in their entirety but without any additional intracranial findings (figure 2C). A clinical diagnosis of bilateral cavernous sinus thrombosis was made and the patient was immediately referred for neurosurgical evaluation. However, the patient and caretakers denied further evaluation and treatment.

\section{DISCUSSION}

Bilateral ophthalmoplegia is a rare clinical scenario. Cases with such presentation need quick and effective ocular and neurological evaluation.
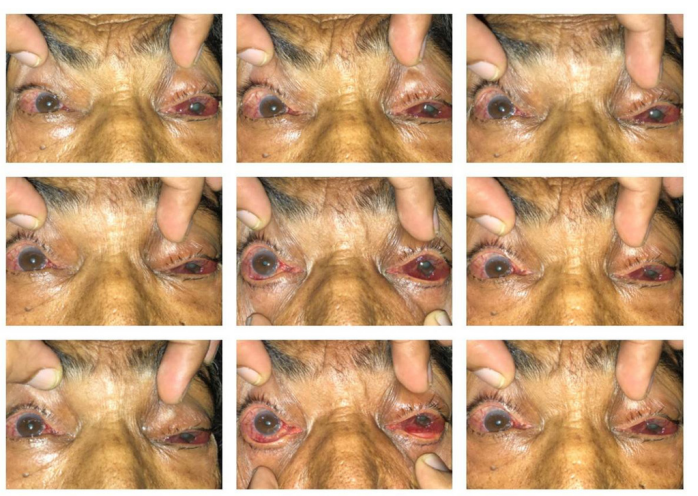

Figure 1 Nine gaze clinical pictures showing severely restricted extraocular motility in both the eyes.
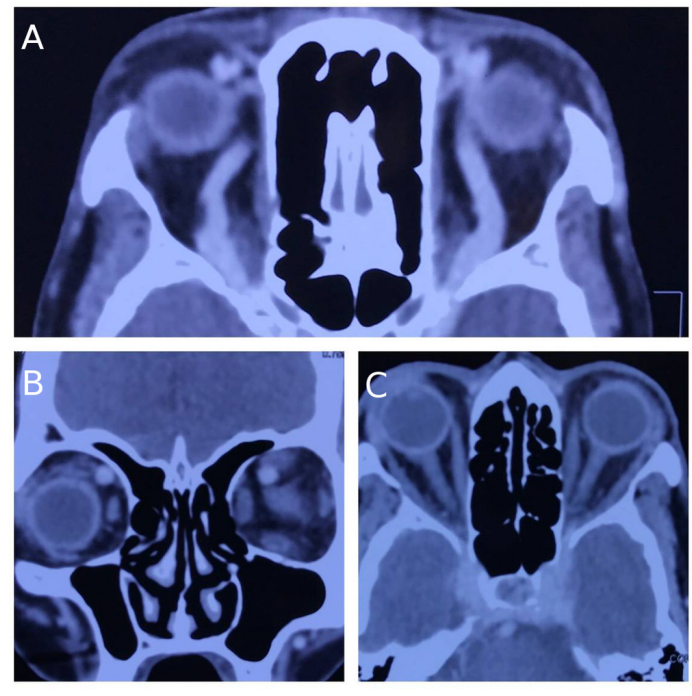

Figure 2 (A) Axial sections of CT showing bilaterally dilated prominent superior ophthalmic veins. (B) Corresponding coronal sections of the $\mathrm{CT}$ showing dilated superior ophthalmic vein along the superonasal aspect. (C) Axial sections of the brain showing bright enhancement along the bilateral cavernous sinus.

Keane et al studied 31 such patients and they found Miller Fisher syndrome in 13 patients $(42 \%)$, Gullain-Barre syndrome in five patients $(16 \%)$, midbrain infarction in four patients $(13 \%)$, myasthenia in three patients (10\%) and one patient each with metastasis, pituitary apoplexy, mucormycosis, botulism, phenytoin toxicity and trauma. $^{12}$

Bilateral ocular paralysis usually hints towards a common pathological site. In the current case, presence of proptosis, chemosis and involvement of all the neurovascular bundles supplying the eye suggests lesion along the orbital apex to cavernous sinus. However, simultaneous involvement of the orbital

\section{Learning points}

While evaluating cases of unilateral or bilateral ocular paralysis, a tailored approach is needed, beginning from detailed clinical evaluation to skilful radiological interpretation to locate the pathology.

- Similarly, considerations of other immunological diseases are equally vital. Considering all the aforementioned differentials and previous observations and reports, inclusion of bilateral cavernous sinus thrombosis as one of the differentials for bilateral simultaneous ocular paralysis is of paramount importance. 
apex is quite unusual as compared with that of cavernous sinus. The aforementioned findings corroborate well with cavernous sinus pathology, which may be due to thrombosis or other infiltrative disease. The involvement is usually unilateral in the initial period with subsequent progression to the contralateral side as the disease process advances. However, in the current case, the patient had bilateral and almost symmetrical ocular findings at presentation, which occurred due to the simultaneous involvement of the cavernous sinus on either side.

Contributors AP, RM, SP and RS have evaluated the case in detail followed by optimal management from the ophthalmic point of view. AP, RM, SP and RS, after critically analysing the educational value of the case, wrote the report together.
Funding The authors have not declared a specific grant for this research from any funding agency in the public, commercial or not-for-profit sectors.

Competing interests None declared.

Patient consent Obtained.

Provenance and peer review Not commissioned; externally peer reviewed.

(C) BMJ Publishing Group Ltd (unless otherwise stated in the text of the article)

2018. All rights reserved. No commercial use is permitted unless otherwise expressly granted.

\section{REFERENCES}

1 Keane JR. Bilateral ocular paralysis: analysis of 31 inpatients. Arch Neurol 2007;64:178

2 Hall DJ, Bazaraa T. A rare case of complete bilateral ophthalmoplegia and ptosis. Age Ageing 2014;43:145-7.

Copyright 2018 BMJ Publishing Group. All rights reserved. For permission to reuse any of this content visit

http://group.bmj.com/group/rights-licensing/permissions.

BMJ Case Report Fellows may re-use this article for personal use and teaching without any further permission.

Become a Fellow of BMJ Case Reports today and you can:

- Submit as many cases as you like

Enjoy fast sympathetic peer review and rapid publication of accepted articles

- Access all the published articles

Re-use any of the published material for personal use and teaching without further permission

For information on Institutional Fellowships contact consortiasales@bmjgroup.com

Visit casereports.bmj.com for more articles like this and to become a Fellow 